ROCZNIK ADMINISTRACJI PUBLICZNEJ 2021 (7)

ARTYKUŁY / ARTICLES

Administracyjne prawo proceduralne

Administrative Procedural Law

AgniesZKa Kastelik-SMAZA ${ }^{1}$

\title{
Procedura prejudycjalna w kontekście prawa do sądu
}

\section{Wprowadzenie}

Procedura pytań prejudycjalnych, przewidziana w art. 267 Traktatu o funkcjonowaniu Unii Europejskiej (dalej: TFUE), postrzegana jest przede wszystkim jako mechanizm współpracy pomiędzy Trybunałem Sprawiedliwości Unii Europejskiej (dalej: Trybunał Sprawiedliwości lub TSUE) a sądami krajowymi ${ }^{2}$. W ostatnim czasie stała się ona znana szerszemu odbiorcy z uwagi na toczący się spór o praworządność, o prymat prawa Unii Europejskiej nad prawem krajowym, w tym rangi konstytucyjnej, czy o kompetencje TSUE do oceny, choćby w sposób pośredni, zgodności prawa krajowego $\mathrm{z}$ prawem unijnym ${ }^{3}$. W dyskusji podnoszonych jest wiele argumentów o charakterze prawnomiędzynarodowym, ustrojowym czy konstytucyjnym, które mają przemawiać za przyznaniem lub wyłączeniem kompetencji TSUE do orzekania w trybie prejudycjalnym. Nierzadko pomija się przy tym fakt, że procedura prejudycjalna odgrywa ważną rolę w zapewnieniu jednostkom skutecznej ochrony ich uprawnień, umożliwiając uzyskanie dostępu do TSUE w sprawach, w których konieczne jest rozstrzygnięcie wątpliwości z zakresu ważności lub wykładni prawa unijnego.

1 Dr Agnieszka Kastelik-Smaza, adwokat, wykładowca szkolenia aplikantów adwokackich Izby Adwokackiej w Bielsku-Białej.

2 Por. np. wyrok w sprawie 244/80, Pasquale Foglia $v$ Mariella Novello, ECLI:EU:C:1981:302; A. Kastelik-Smaza, Pytania prejudycjalne do Europejskiego TrybunaŁu Sprawiedliwości a ochrona praw jednostki, Warszawa 2010, s. 21.

3 E. Łętowska, Czego ucza odpowiedzi na pytania prejudycjalne dotyczace polskiego wymiaru sprawiedliwości, „Palestra” 2020, nr 5, https://palestra.pl/pl/czasopismo/ wydanie/5-2020/artykul/czego-ucza-odpowiedzi-na-pytania-prejudycjalne-dotyczace -polskiego-wymiaru-sprawiedliwosci (dostęp: 1.10.2021); Skutki wyroków Trybunału Sprawiedliwości i Sądu Najwyższego dotyczacych Izby Dyscyplinarnej Sądu Najwyższego i Krajowej Rady Sądownictwa (debata w redakcji „Europejskiego Przegladu Sądowego” w dniu 17.12.2019 r.), „Europejski Przegląd Sądowy” 2020, nr 1, s. 4. 
Celem niniejszego opracowania jest analiza procedury prejudycjalnej $\mathrm{w}$ kontekście różnych aspektów związanych z prawem do sądu. W pierwszej kolejności należy tutaj wspomnieć o roli orzecznictwa prejudycjalnego w ukształtowaniu unijnych gwarancji prawa do sądu. Istotny rozwój dorobku w tym zakresie przyniosły wydane $\mathrm{w}$ ostatnich latach wyroki dotyczące niezawisłości sędziowskiej i niezależności sądów. Przedmiotem dalszych rozważań będzie kwestia, w jaki sposób zaprezentowane we wspominanych wyrokach tezy odnośnie przymiotów, jakie powinien posiadać sąd krajowy, wpłynęły na stosowanie art. 267 TFUE, a więc na samą procedurę prejudycjalną. Zbadane zostanie także, czy zadanie pytania prejudycjalnego lub, wręcz przeciwnie, odmowa zadania pytania prejudycjalnego, może stanowić naruszenie prawa jednostki do sądu.

\section{Rola procedury prejudycjalnej w kształtowaniu gwarancji prawa do sądu}

Prawo do sądu stanowi ogólną zasadę prawa Unii Europejskiej, sformułowaną po raz pierwszy na gruncie unijnym przez Trybunał Sprawiedliwości ${ }^{4}$, który wywiódł ją z tradycji konstytucyjnych państw członkowskich oraz z art. 6 i 13 Europejskiej Konwencji o Ochronie Praw Człowieka i Podstawowych wolności (dalej: Konwencja) $)^{5}$.

Trybunał Sprawiedliwości w ramach procedury prejudycjalnej wydał wiele wyroków dotyczących pojęcia sądu i prawa do sądu. Przede wszystkim sformułował zasadę skutecznej ochrony sądowej w dziedzinach objętych prawem Unii ${ }^{6}$. Zdefiniował także pojęcie sądu w rozumieniu pra-

4 Wyrok z dnia 15 maja 1986 r. w sprawie 222/84, Marguerite Johnston przeciwko Chief Constable of the Royal Ulster Constabulary, ECLI:EU:C:1986:206; wyrok z dnia 15 października 1987 r. w sprawie 222/86, Union nationale des entraîneurs et Cadres techniques professionnels du football (Unecatef) p. Georges Heylensi in., ECLI:EU:C:1987:442; wyrok z dnia 27 listopada 2001 r. w sprawie C-424/99, Komisja p. Austrii, ECLI:EU:C:2001:642; wyrok z dnia 25 lipca 2002 r. w sprawie C-50/00 P, Unión de Pequeños Agricultores p. Radzie, ECLI:EU:C:2002:462; wyrok z dnia 19 czerwca 2003 r. w sprawie C-467/01, Ministerodelle Finanze v EribrandSpA., ECLI:EU:C:2003:364; wyrok z dnia 13 marca $2007 \mathrm{w}$ sprawie C-432/05 Unibet (London) Ltd i Unibet (International) Ltd p. Justitiekanslern, ECLI:EU:C:2007:163.

5 Konwencja o Ochronie Praw Człowieka i Podstawowych Wolności z dnia 4 listopada 1950 r. (Dz. U. 1993 Nr 61, poz. 284). Artykuł 6 Konwencji zapewnia każdemu „prawo do sprawiedliwego i publicznego rozpatrzenia jego sprawy w rozsądnym terminie przez niezawisły i bezstronny sąd ustanowiony ustawą przy rozstrzyganiu o jego prawach i obowiązkach o charakterze cywilnym albo o zasadności każdego oskarżenia w wytoczonej przeciwko niemu sprawie karnej”. Artykuł 13 Konwencji mówi z kolei o prawie do skutecznego środka odwoławczego do właściwego organu państwowego w razie naruszenia praw i wolności zawartych w Konwencji.

6 Wyrok z dnia 10 kwietnia 1984 r. w sprawie 14/83, Sabine von Colson and Elisabeth Kamannp. Land Nordrhein-Westfalen, ECLI:EU:C:1984:153; wyrok z dnia 5 marca 1996 r. w połączonych sprawach C-46/93 oraz C-48/93, Brasseriedu Pêcheur v. Niemcy $i$ The Queen p. Secretary of State for Transport ex parte FactortameLtd $i$ in., 
wa unijnego poprzez wykładnię obecnego art. 267 TFUE, a także różnych aktów prawa pochodnego, m.in. decyzji ramowej w sprawie europejskiego nakazu aresztowania ${ }^{7}$, czy rozporządzenia o jurysdykcji, uznawaniu i wykonywaniu orzeczeń w sprawach cywilnych i handlowych ${ }^{8}$. Po wejściu w życie Traktatu z Lizbony przedmiotem wykładni TSUE jest również art. 47 Karty Praw Podstawowych (dalej: KPP) ${ }^{9}$ i art. 19 Traktatu o Unii Europejskiej (dalej: TUE) ${ }^{10}$.

W ostatnich latach problematyka dotycząca prawa do sądu jest szczególnie żywa w orzecznictwie Trybunału Sprawiedliwości. Jako przykład można wskazać szeroko omawiany w doktrynie wyrok w sprawie sędziów portugalskich ${ }^{11}$, w którym TSUE dogłębnie przeanalizował problematykę skutecznej ochrony sądowej i cech, które powinien posiadać sąd unijny. Wskazał w szczególności, że niezawisłość sądów krajowych ma zasadnicze znaczenie $w$ szczególności dla prawidłowego funkcjonowania systemu współpracy sadowej pod postacia mechanizmu odesłania prejudycjalnego przewidzianego $w$ art. 267 TFUE, jako że (...) mechanizm ten może zostać uruchomiony przez organ, którego zadaniem jest stosowanie prawa Unii,

ECLI:EU:C:1996:79. Na temat efektywnej ochrony prawnej zob. N. Półtorak, Kto jest związany zasada efektywnej ochrony prawnej - uwagi na tle orzecznictwa Trybunału Sprawiedliwości w sprawie „Unión de PequeñosAgricultores”, „Kwartalnik Prawa Publicznego" 2002, nr 3, s. 187; N. Półtorak, Ochrona uprawnień wynikajacych z prawa Unii Europejskiej w postępowaniach krajowych, Warszawa 2010, s.83; K. Scheuring, Ochrona praw jednostki w postępowaniach przed sądami wspólnotowymi, Warszawa 2007, s. 63.

7 Decyzja ramowa Rady z dnia 13 czerwca 2002 r. w sprawie europejskiego nakazu aresztowania i procedury wydawania osób między państwami członkowskimi, Dz. U. L 190 z 18.7.2002, s. 1. Por. wyrok z dnia 17 lipca 2008 r. w sprawie C-66/08, Szymon Kozłowski, ECLI:EU:C:2008:437; wyrok z dnia 16 listopada 2010 r. w sprawie C-261/09, GaetanoMantello, ECLI:EU:C:2010:683.

8 Rozporządzenie Parlamentu Europejskiego i Rady (UE) nr 1215/2012 z dnia 12 grudnia 2012 r. w sprawie jurysdykcji i uznawania orzeczeń sądowych oraz ich wykonywania w sprawach cywilnych i handlowych, ELI: http://data.europa.eu/eli/ reg/2012/1215/oj.Por. opinię rzecznika generalnego Michala Bobeka z dnia 27 października 2016 r. w sprawie C-551/15, Pula Parking d.o.o. p. Svenowi Klausowi Tederahnowi, ECLI:EU:C:2016:825.

9 Karta Praw Podstawowych Unii Europejskiej, ELI: http://data.europa.eu/eli/ treaty/char_2012/oj. Art. 47 KPP gwarantuje prawo do skutecznego środka prawnego i dostępu do bezstronnego sądu.

10 Traktat o Unii Europejskiej (wersja skonsolidowana) z dnia 13 grudnia 2007 r., ELI: http://data.europa.eu/eli/treaty/teu_2012/oj. Art. 19 ust. 1 TUE zobowiązuje państwa członkowskie do ustanawiania środków niezbędnych do zapewnienia skutecznej ochrony prawnej w dziedzinach objętych prawem Unii.

11 Wyrok z dnia 27 lutego 2018 r. w sprawie C-64/16, Associação Sindicaldos Juízes Portuguesesp. Tribunal de Contas, ECLI:EU:C:2018:117; A. Sikora, Glosa do wyroku TSUE $z$ 27.02.2018 r., C-64/16, Associação Sindicaldos Juizes Portugueses (art. 19 TUE jako autonomiczny i samodzielny wzorzec kontroli legalności), „Państwo i Prawo” 2018, nr 11, s. 133. 
spetniający w szczególności rzeczone kryterium niezawisłości. Pojęcie niezawisłości oznacza między innymi, że dany organ wypetnia swe zadania sądownicze w petni autonomicznie, nie podlegając żadnej hierarchii stużbowej, ani nie będac podporzadkowanym komukolwiek i nie otrzymując nakazów czy wytycznych z jakiegokolwiek źródła, oraz że jest on w ten sposób chroniony przed ingerencja i naciskami zewnętrznymi, mogącymi zagrozić niezależności osądu jego członków i wplywać na ich rozstrzygnięcia (...).

Wiele ważnych tez zawarł także Trybunał Sprawiedliwości w swoich odpowiedziach na pytania prejudycjalne polskich sądów.

$\mathrm{W}$ pierwszej kolejności należy tutaj wskazać na wyrok w sprawie A.K. ${ }^{12}$, w którym TSUE wypowiadał się na temat niezależności sądów i niezawisłości sędziowskiej w kontekście reformy sądownictwa w Polsce. Podkreślił przy tym, że wymóg niezawisłości sędziowskiej, stanowiącej integralny element sadzenia, wchodzi w zakres istoty prawa do skutecznej ochrony sadowej oraz prawa podstawowego do rzetelnego procesu sądowego, które to prawo ma fundamentalne znaczenie jako gwarancja ochrony wszystkich praw wywodzonych przez jednostki z prawa Unii, oraz zachowania wartości wspólnych państwom członkowskim, wyrażonych $w$ art. 2 TUE, $w$ szczególności wartości państwa prawnego. Przypomniał ponadto, że sądy powinny być niezależne zarówno od stron, jak i od władzy wykonawczej i ustawodawczej.

$\mathrm{W}$ wyroku w sprawie $A \cdot B \cdot{ }^{13}$ TSUE zwrócił szczególną uwagę na obowiązek zagwarantowania prawa do skutecznego środka odwoławczego, uznając, że ograniczenie, a w szczególności wyłączenie sądowej kontroli rozstrzygnięć co do przedstawienia kandydatów na sędziów SN może stanowić naruszenie art. 19 ust. 1 akapit drugi TUE.

W sprawie Miasto Łowicz ${ }^{14}$ Trybunał Sprawiedliwości wskazał, że sądy orzekające w sprawach związanych ze stosowaniem prawa Unii muszą odpowiadać wymogom skutecznej ochrony sądowej, których spełnienie powinno zagwarantować państwo członkowskie, regulując w sposób właściwy organizację krajowego wymiaru sprawiedliwości.

We wspomnianym orzecznictwie, Trybunał Sprawiedliwości podkreślił, że zgodnie z art. 19 TUE państwa członkowskie mają obowiązek zapewnić skuteczne środki ochrony prawnej w każdej sprawie, w której występuje związek z prawem Unii. Jednocześnie z orzeczeń tych wynika, że przedmiotowy związek należy rozumieć bardzo szeroko. TSUE wskazał też, że

12 Wyrok z dnia 19 listopada 2019 r. w połączonych sprawach C-585/18, C-624/18 i C-625/18, A.K. p. Krajowej Radzie Sądownictwa i CP i DO p. Sądowi Najwyższemu, ECLI:EU:C:2019:982; A. Grzelak, A. Sakowicz, Wymóg niezależności sq̨du krajowego jako element skutecznej ochrony sadowej(uwagi na tle wyroku TS z 19.11.2019 r. dla polskiego wymiaru sprawiedliwości), Państwo i Prawo 5/2020, s. 59.

13 Wyrok z dnia 2 marca 2021 r. w sprawie C-824/18, A.B. $i$ in. p. Krajowa Rada Sąownictwa, ECLI:EU:C:2021:153.

14 Wyrok z dnia 26 marca 2020 r. w połączonych sprawach C-558/18 i C-563/18, Miasto Łowicz p. Skarbowi Państwa, ECLI:EU:C:2020:234. 
art. 19 TUE należy interpretować w świetle art. 47 KPP i potwierdził, że oba te przepisy mają walor bezpośredniej skuteczności, a więc jednostki mogą się na nie bezpośrednio powoływać przed sądami państw członkowskich. Trybunał Sprawiedliwości wiele uwagi poświęcił niezawisłości sądów krajowych, wskazując, że ma ona fundamentalne znaczenie dla porządku prawnego Unii Europejskiej. Jest elementem koniecznym dla zagwarantowania prawa podstawowego przewidzianego w art. 47 karty, czyli prawa do sądu. Z kolei prawo do sądu jest gwarancją ochrony wszystkich praw wywodzonych przez jednostki z prawa Unii.

\section{Wpływ orzecznictwa dotyczącego prawa do sądu na stosowanie procedury prejudycjalnej}

Trybunał Sprawiedliwości wskazywał wielokrotnie, że art.267 TFUE przyznaje sądom krajowym jak najszersze uprawnienie do wystąpienia z pytaniem dotyczącym wykładni lub ważności przepisów unijnych, jeśli odpowiedź na to pytanie jest niezbędna do rozstrzygnięcia sprawy. Żaden przepis prawa krajowego nie może stanowić przeszkody dla skorzystania przez sąd z procedury prejudycjalnej ${ }^{15}$. Jeśli taki przepis istnieje, należy go pominąć bez potrzeby zwrócenia się o jego usunięcie przez ustawodawcę lub sąd konstytucyjny ${ }^{16}$.

W kilku ostatnich sprawach, m.in. w wyroku Miasto Łowicz, czy w opinii rzecznika generalnego dotyczącej sędziów rumuńskich ${ }^{17}$, wskazano

15 Wyrok z dnia 16 stycznia 1974 r. w sprawie 166/73, Rheinmühlen-Düsseldorf p. Einfuhr- Und Vorratsstelle für Getreide und Futtermittel. ECLI:EU:C:1974:3; wyrok z dnia 22 czerwca 2010 r. w połączonych sprawach C-188/10, Aziz Melki i C-189/10, Sélim Abdeli, ECLI:EU:C:2010:363; z dnia 5 kwietnia 2016 r. w sprawie C-689/13, Puligienica Facility EscoSpA (PFE) v. AirgestSpA, ECLI:EU:C:2016:199; wyrok z dnia 5 października 2010 r. w sprawie C-173/09, Georgi Ivanov Elchinov v Natsionalnazdravnoosiguritelna kasa, EU:C:2010:581. W wyroku w sprawach C-558/18 i C-563/18 Miasto Łowicz wskazano, że jeżeli wprowadzone zmiany normatywne skutkowałyby uniemożliwieniem udzielenia odpowiedzi na zadane pytania prejudycjalne i wykluczeniem możliwości powtórnego ich zadania, doszłoby do naruszenia art. 267 TFUE oraz art. 4 ust. 3 TUE.

16 Wyrok z dnia 14 grudnia 1995 r. w sprawie C-312/93, Peterbroeck, Van CampenhoutઐCie SCS p. Belgii, ECLI:EU:C:1995:437; Jak wskazał TSUE w wyroku w sprawie A.B. „To samo dotyczy zmiany w prawie krajowym, której szczególnym skutkiem jest zapobieżenie wypowiedzeniu się przez Trybunał w przedmiocie wniosków o wydanie orzeczenia w trybie prejudycjalnym, które do niego wpłynęły, i wykluczenie jakiejkolwiek możliwości przyszłego powtórnego wystąpienia przez sąd krajowy z analogicznymi wnioskami".

17 Opinia rzecznika generalnego Bobeka z dnia 4 marca $2021 \mathrm{w}$ połączonych sprawach C-357/19 i C-379/19, Euro Box Promotion i in., ECLI:EU:C:2021:170. Odnosząc się do sankcji dyscyplinarnych za nierespektowanie orzeczeń Trybunału Konstytucyjnego, rzecznik generalny stwierdził, że prawo Unii nie pozwala na wszczęcie postępowania dyscyplinarnego wobec sędziego jedynie z powodu wystąpienia przez niego do 
ponadto na niedopuszczalność postępowania dyscyplinarnego wobec sędziego krajowego, w związku ze skierowaniem pytania prejudycjalnego, nawet jeśli to pytanie $\mathrm{w}$ późniejszej ocenie TSUE okazało się niedopuszczalne. Trybunał Sprawiedliwości podkreśla, że już samo ryzyko takiego postępowania może negatywnie wpłynąć na wykonywanie przez sędziów krajowych ich obowiązków jako sędziów unijnych, którzy mają zapewniać skuteczną ochronę sądową uprawnień wynikających z prawa Unii ${ }^{18}$.

W tym kontekście, należy zwrócić uwagę, że w najnowszym orzecznictwie TSUE, niezależnie od podkreślania szerokich kompetencji sądów do występowania z pytaniami prejudycjalnymi, pojawiły się także wątki wskazujące, że brak niezawisłości może doprowadzić do utraty przez sąd krajowy kompetencji do wystąpienia z pytaniem prejudycjalnym.

Już w swoim wcześniejszym orzecznictwie dotyczącym pojęcia sądu $\mathrm{w}$ rozumieniu art. 267 TFUE, Trybunał wskazywał, że jednym z kluczowych kryteriów uznania danego organu krajowego za sąd, jest jego niezawisłość ${ }^{19}$. Orzecznictwo to nie dotyczyło jednak sądów państw członkowskich sensu stricto, ale organów quasi-sądowych, i zmierzało raczej do poszerzenia kręgu podmiotów uprawnionych do występowania z pytaniami prejudycjalnymi ${ }^{20}$.

Tradycyjnie Trybunał nie kwestionował kompetencji do wystąpienia z pytaniem prejudycjalnym przez podmiot będący częścią struktury sądownictwa krajowego. Podejście to opierało się na domniemaniu przynajmniej obiektywnej niezawisłości sądu odsyłającego ${ }^{21}$. W najnowszym

Trybunału Sprawiedliwości z wnioskiem o wydanie orzeczenia w trybie prejudycjalnym, w którym ów sędzia kwestionuje orzecznictwo krajowego sądu konstytucyjnego i rozważa możliwość jego niezastosowania.

18 Por. Wyrok TS z dnia 5 lipca 2016 r. w sprawie C-614/14, Postępowanie karne przeciwko Atanasowi Ognyanovowi, ECLI:EU:C:2016:514.

19 Zgodnie $z$ utrwalonym orzecznictwem przy ustalaniu, czy organ występujacy $z$ danym wnioskiem o wydanie orzeczenia $w$ trybie prejudycjalnym ma charakter „sadu” w rozumieniu art. 267 TFUE, co stanowi kwestię regulowang wyłacznie prawem Unii, Trybunat bierze pod uwagę szereg okoliczności, takich jak podstawa prawna ustanowienia organu, jego stały charakter, obligatoryjność jego jurysdykcji, kontradyktoryjność postępowania, stosowanie przez organ przepisów prawa oraz jego niezawisłość. Wyrok z dnia 21 stycznia 2020 r. w sprawie C-274/14, Banco de Santander, ECLI:EU:C:2020:17.

20 Por. np. wyrok z dnia 11 czerwca 1987 r. w sprawie 14/86, Pretore di Salo p.X, ECLI: ECLI:EU:C:1987:275; wyrok z dnia 17 września 1997 r. w sprawie C-54/96, Dorsch Consult Ingenieurs gesellschaft p. Bundesbaugesellschaft Berlin, ECLI:EU:C:1997:413; wyrok z dnia 6 października $1981 \mathrm{r}$. w sprawie 246/80, Broekmeulen v. Huisarts Registratie Commissie, ECLI:EU:C:1981:218; wyrok z dnia 13 grudnia 2012 r. w sprawie C-465/11, Forposta SA i ABC Direct Contact sp. $z$ o.o. p. Poczcie Polskiej SA, ECLI:EU:C:2012:801; R. Grzeszczak, M. Krajewski, „Sad” w świetle przepisów art. 47 KPP oraz art. 267 TFUE, „Europejski Przegląd Sądowy” 2014, nr 6, s. 4.

21 Jak wskazała rzecznik generalna Juliane Kokott w opinii z dnia 23 stycznia $2020 \mathrm{r}$. w sprawie C-658/18,UX p. Governo della Repubblica italiana, ECLI:EU:C:2020:33: Zgodnie $z$ orzecznictwem wymóg niezawisłości organu odsyłającego obejmuje dwa 
orzecznictwie, coraz częściej sygnalizuje się jednak, że to domniemanie może zostać obalone.

W odniesieniu do procedury prejudycjalnej ma to między innymi taki skutek, że pojawia się coraz więcej wątków, w których kwestionowana jest niezawisłość sądów państw członkowskich i ich kompetencje do wystąpienia $\mathrm{z}$ pytaniem prejudycjalnym. Takie wątpliwości podnoszone są nawet przez same sądy odsyłające.

Przykładowo w sprawie C-658/18 włoski sędzia pokoju zgłosił zastrzeżenia co do własnej obiektywnej niezawisłości, wskazując na swoje szczególne warunki zatrudnienia. Wątpliwości te zrodziły się właśnie w związku z orzecznictwem Trybunału w sprawie sędziów portugalskich i niezależności polskich sądów ${ }^{22}$. Warto zaznaczyć, że pojawiły się one pomimo tego, że Trybunał uznał już w swoim wcześniejszym orzecznictwie uprawnienie włoskich sędziów pokoju do występowania z pytaniami prejudycjalnymi ${ }^{23}$.

Innym sądem, który kwestionował własny status na tle art.267 TFUE był sąd administracyjny w Wiesbaden w sprawie C-272/1924. Sąd podniósł pewne argumenty, wskazujące na jego zależność od władzy ustawodawczej i wykonawczej w procesie powoływania sędziów i sprawowania przez nich

aspekty: niezawisłość obiektywna, „zewnętrzna” oraz niezawisłość subiektywna, „wewnętrzną" (...). Obiektywna niezawistość zakłada, że sąd wykonuje swoje funkcje w petni autonomicznie, bez podlegania żadnej hierarchii służbowej lub podporzadkowania komukolwiek, i nie otrzymuje nakazów czy wskazówek $z$ jakiegokolwiek źródła (...). Trybunał powinien raczej wyjść z założenia, że sady państw członkowskich posiadaja wystarczająca obiektywna niezawisłość. Domniemanie to jest niezbędne już choćby ze względu na wzajemne zaufanie co do systemów sądownictwa państw członkowskich, które musi zostać przyjęte również przez Trybunał (...). Subiektywna niezawisłość łączy się z pojęciem bezstronności i dotyczy zachowania jednakowego dystansu do stron sporu i ich interesów w odniesieniu do jego przedmiotu. Aspekt ten wymaga przestrzegania obiektywizmu oraz braku wszelkiego interesu w rozstrzygnięciu sporu poza ścisłym stosowaniem przepisu prawa (...).

22 Wątpliwości te odnosiły się w szczególności do wynagradzania sędziów pokoju, w tym prawa do płatnego urlopu, a także do faktu, że wykonywanie przez nich funkcji jest ograniczone do czterech lat z możliwością przedłużenia na kolejne cztery lata. W świetle najnowszego orzecznictwa Trybunału w sprawie wynagrodzeń sędziów w Portugalii i niezależności polskich sądów wynagrodzenie sędziów i czasowy charakter sprawowania przez nich funkcji rzeczywiście odgrywaja rolę przy ocenie obiektywnej niezawisłości sąów (...). Z orzecznictwa wynika przy tym również, że niezawisłość rozumiana $w$ ten sposób jest warunkiem wstępnym prawa organu do wystąpienia $z$ odesłaniem prejudycjalnym na podstawie art. 267 TFUE. Por. Opinia rzecznika generalnego Juliane Kokott w sprawie C-658/18, UX.

23 Zobacz na przykład wyrok z dnia 2 grudnia 2010 r. w sprawie C-225/09, Edyta Joanna Jakubowska p. Alessandro Maneggia, ECLI:EU:C:2010:729; postanowienie z dnia 19 stycznia 2012 r. w sprawie C-496/10, Postępowanie karne p. Aldo Patriciello, ECLI:EU:C:2012:24); postanowienie z dnia 21 marca 2013 r. w sprawie C-522/11, Procura della Repubblica p. Abdoul Khadre Mbaye, ECLI:EU:C:2013:190.

24 Wyrok z dnia 9 lipca 2020 r. w sprawie C-272/19, VQ p. Land Hessen, ECLI:EU:C:2020:535. 
funkcji ${ }^{25}$. Następnie wskazał, że w świetle orzecznictwa w sprawach polskich, najprawdopodobniej nie spełnia on kryteriów uznania za sąd w rozumieniu art. 267 TFUE i nie może zadawać pytań prejudycjalnych.

Trybunał nie podzielił wspomnianych wyżej wątpliwości włoskiego sędziego pokoju ani sądu niemieckiego. W obu sprawach odwołał się do swojego wyroku w sprawie A.K., w którym orzekł, że pojedyncze aspekty prawa krajowego nie przesądzają o braku niezależności sądu. Inaczej może być w przypadku kumulacji czynników prawnych i faktycznych, których zbieg może wzbudzić w jednostce wątpliwości co do niezależności sądu i podważyć zaufanie, jakie sądownictwo powinno budzić w jednostkach w społeczeństwie demokratycznym ${ }^{26}$.

W rezultacie Trybunał nie zakwestionował kompetencji żadnego z tych sądów do zadawania pytań prejudycjalnych.

Na tle najnowszego orzecznictwa Trybunału Sprawiedliwości dotyczącego prawa do sądu doszło jednakże do rewizji statusu niektórych organów państw członkowskich w kontekście procedury prejudycjalnej. Tak stało się z hiszpańskim Tribunal Económico Administrativo Central, rozstrzygającym sprawy podatkowe. We wcześniejszym orzeczeniu w sprawie $G a-$ balfrisa, został on uznany za sąd w rozumieniu art. 267 TFUE $^{27}$. Jednakże w niedawnym orzeczeniu w sprawie Banco de Santander ${ }^{28}$ TSUE stwierdził, że w świetle zmian traktatowych, brzmienia Karty Praw Podstawowych i najnowszego orzecznictwa, organ ten nie spełnia kryterium niezawisłości, nie jest więc sądem i nie może już kierować pytań prejudycjalnych do Trybunału ${ }^{29}$.

25 Chodziło o następujące okoliczności: Po pierwsze, sędziowie sa mianowani i awansowani przez ministra sprawiedliwości, po drugie, ocena sędziów jest regulowana przez ministerstwo sprawiedliwości zgodnie z tymi samymi przepisami, które maja zastosowanie do urzędników, po trzecie, dane osobowe i informacje stużbowe dotyczace sędziów sq administrowane przez to ministerstwo, które ma wobec tego dostęp do tych danych, po czwarte, $w$ celu zaspokojenia tymczasowego zapotrzebowania kadrowego urzędnicy moga być powolywani jako sędziowie tymczasowi i, po piąte, wspomniane ministerstwo określa organizację zewnętrzna i wewnętrzna sądów, wyznacza przydziat personelu, środków komunikacji i sprzętu komputerowego sądów oraz decyduje również o wyjazdach stużbowych sędziów za granicę. Por. Wyrok w sprawie C-272/19, VQ.

26 Wyrok w połączonych sprawach C-585/18, C-624/18 i C-625/18, A.K.

27 Wyrok z dnia 21 marca $2000 \mathrm{r}$. w połączonych sprawach od C-110/98 do C-147/98, Gabalfrisa i in. p. Agencia Estatal de Administración Tributaria (AEAT), ECLI:EU:C:2000:145.

28 Wyrok w sprawie C-274/14, Banco de Santander SA.

29 Rzecznik generalny Gerard Hogan w swojej opinii z dnia 1 października 2019 r. w sprawie C-274/14, Banco de Santander SA, ECLI:EU:C:2019:802 wskazał, że „od czasu wydania wyroku z dnia 21 marca 2000 r., Gabalfrisa i in. (od C-110/98 do C-147/98, EU:C:2000:145), prawo Unii ulegało zmianom. Artykuł 2 TUE stanowi obecnie, że Unia opiera się na wartościach państwa prawnego. Artykuł 19 ust. 2 TUE stanowi, że sędziowie i rzecznicy generalni Trybunału Sprawiedliwości sq wybierani spośród osób o niekwestionowanej niezależności. Artykuł 47 Karty praw podstawowych Unii Europejskiej (...) gwarantuje skuteczny środek prawny i rozpatrzenie sprawy przez „niezawisły i bezstronny sąd”. W tym kontekście należy zwrócić uwagę, że Tribunal 
Tym samym orzecznictwo dotyczące prawa do sądu, wydane w odpowiedzi na pytania prejudycjalne co do wykładni art. 19 TFUE czy art. 47 KPP, wpłynęło także na wykładnię samego art. 267 TFUE, a w tym pojęcia sądu w rozumieniu tego przepisu, oraz na stosowanie procedury prejudycjalnej. W szczególności doprowadziło do pojawienia się wątpliwości odnośnie kompetencji sądów krajowych wynikających z art. 267 TFUE oraz do faktycznej rewizji statusu niektórych organów państw członkowskich $\mathrm{w}$ ramach procedury prejudycjalnej.

\section{Zapewnienie prawa do sądu poprzez zadanie pytania prejudycjalnego}

Rozważając znaczenie procedury prejudycjalnej w kontekście prawa do sądu, należy wskazać, że w sprawach, w których występuje zagadnienie z zakresu prawa unijnego, skierowanie przez sąd krajowy pytania prejudycjalnego do Trybunału Sprawiedliwości może mieć istotne znaczenie dla zagwarantowania jednostce prawa do skutecznej ochrony sądowej.

System ochrony prawnej w Unii Europejskiej ma charakter dualistyczny i zapewniany jest z jednej strony przez Sąd i Trybunał Sprawiedliwości, z drugiej zaś przez sądy państw członkowskich ${ }^{30}$. Z uwagi na wysokie wymagania stawiane podmiotom indywidualnym $\mathrm{w}$ ramach skarg bezpośrednich, jednostki mogą uzyskać bezpośredni dostęp do Sądu Unii Europejskiej jedynie $\mathrm{w}$ drodze wyjątku ${ }^{31}$. W pozostałym zakresie ochronę ich uprawnień mają zapewnić sądy krajowe.

Deficyt ochrony w tak ukształtowanym systemie, wyrównuje w pewnym stopniu procedura prejudycjalna. Dzięki niej strona postępowania krajowego może uzyskać dostęp do sądu unijnego za pośrednictwem sądu

Económico Administrativo Central nie jest sądem państwa członkowskiego sensu stricto. W polskiej wersji językowej jego nazwę przetłumaczono co prawda jako „regionalny sąd administracyjny ds. podatkowych”, ale w uzasadnieniu wyroku wskazuje się, że członkowie tego sądu są „urzędnikami służby cywilnej mianowanymi za zgodą ministra”. Mogą oni zostać odwołani dekretem królewskim na wniosek ministra (brak niezawisłości w aspekcie zewnętrznym). Ponadto, zarówno dyrektor generalny ds. podatkowych ministerstwa gospodarki i finansów, który może wnieść nadzwyczajną skargę na decyzję TEAC, jak i dyrektor generalny lub dyrektor departamentu krajowej agencji administracji podatkowej, który wydał akt wskazany w tej decyzji, zasiadają w składzie specjalnej izby TEAC, która rozpatruje tę skargę (brak niezawisłości w aspekcie wewnętrznym).

$30 \mathrm{~W}$ doktrynie wskazuje się na rozróżnienie pomiędzy sądami unijnymi w znaczeniu ustrojowym (Trybunał Sprawiedliwości, Sąd) oraz w znaczeniu funkcjonalnym (sądy krajowe orzekające w sprawach z elementem unijnymi). Por. A. Wróbel, Uwagi w kwestii prawa obywateli Unii Europejskiej do sądu wspólnotowego (główne tezy) [w:] Prawo polskie a prawo Unii Europejskiej. Konferencja wydziałowa Wydziału Prawa i Administracji UW 28 luty 2003, E. Piontek (red.), Warszawa 2003, s. 240.

31 Por. A. Zawidzka, Locus standi osób fizycznych i prawnych na podstawie art. 230 TWE - czas na zmiany [w:] Szkice z prawa Unii Europejskiej, t. I, Prawo instytucjonalne, E. Piontek, A. Zawidzka (red.), Kraków 2003, s. 199; 
krajowego i uzyskać rozstrzygnięcie pewnego fragmentu swojej sprawy przez Trybunał Sprawiedliwości. Często owo zagadnienie z zakresu prawa unijnego jest kluczowe dla wyniku procesu ${ }^{32}$. W związku $\mathrm{z}$ tym procedura prejudycjalna, mimo że zasadniczo jest procedurą współpracy pomiędzy sądami krajowymi a Trybunałem Sprawiedliwości, uważana jest także za pośredni środek ochrony uprawnień jednostki.

Powyższe rozważania prowadzą do wniosku, że jeśli sprawa rozpoznawana jest przez sąd państwa członkowskiego, który nie spełnia kryteriów niezawisłości, niezbędnych do uznania go za sąd w rozumieniu art. 267 TFUE, może to prowadzić do pozbawienia jednostki prawa do sądu na dwóch płaszczyznach, tj. do rozpoznania jej sprawy przez niezawisły sąd krajowy, ale także do pozbawienia jej prawa dostępu do Trybunału Sprawiedliwości w ramach procedury prejudycjalnej.

Rola procedury prejudycjalnej $\mathrm{w}$ zapewnieniu jednostce skutecznej ochrony prawnej w sprawach $\mathrm{z}$ elementem unijnym, została dostrzeżona w orzecznictwie sądów konstytucyjnych państw członkowskich oraz Europejskiego Trybunału Praw Człowieka. Z orzecznictwa tego wynika, że naruszenie obowiązku zadania pytania prejudycjalnego przez sąd ostatniej instancji ${ }^{33}$ może stanowić naruszenie prawa do sądu.

Taki pogląd prezentuje m.in. niemiecki Federalny Sąd Konstytucyjny (dalej: FSK), od czasu słynnego orzeczenia Solange II z lat 80-tych ${ }^{34}$. Zdaniem FSK Trybunał Sprawiedliwości jest organem władzy sądowniczej (tzw. sędzią ustawowym) w rozumieniu art. 101 niemieckiej Ustawy Zasadniczej (dalej: GG) ${ }^{35}$. Naruszenie obowiązku zadania pytania prejudycjalnego stanowi jednocześnie pogwałcenie konstytucyjnego prawa do rozpatrzenia sprawy przez właściwy sąd i może być podstawą skargi konstytucyjnej. FSK wskazuje, że Trybunał Sprawiedliwości jest organem ochrony prawnej,

32 Szerzej na ten temat A. Kastelik-Smaza, Pytania..., s. 85.

33 Zgodnie z art. 267 ust. 3 TFUE w przypadku, gdy pytanie dotyczące wykładni lub ważności prawa unijnego ,jest podniesione w sprawie zawisłej przed sądem krajowym, którego orzeczenia nie podlegają zaskarżeniu według prawa wewnętrznego, sąd ten jest zobowiązany wnieść sprawę do Trybunału”. Warto zauważyć, że w odniesieniu do polskiej procedury cywilnej TSUE przesądził, że w sprawach, w których przysługuje skarga kasacyjna, sądem zobowiązanym do zadania pytania prejudycjalnego nie jest sąd drugiej instancji, lecz dopiero Sąd Najwyższy - por. wyrok z dnia 21 grudnia $2016 \mathrm{r}$. w sprawie C-119/15, Biuro podróży „Partner” Sp. z o.o. sp.k. w Dąbrowie Górniczej przeciwko Prezesowi Urzędu Ochrony Konkurencji i Konsumentów, ECLI:EU:C:2016:987.

34 Postanowienie $\mathrm{z}$ dnia 22 października 1986 r. w sprawie 2 BVR 197/83 (Solange II) BVerfGE 73, 339; Na ten temat por. m.in. K. Schiller, Willkürliche Verletzung der Vorlagepflicht an den EuGH. Voraussetzungen für einen Verstoß gegen Art. 101 Abs. 1 Satz 2 GG, Recht der internationalen Wirtschaft 1988, s. 452; Ch. Velder, Ein neuer gesetzlicher Richter?, „Neue juristische Wochenschrift” 1987, s. 526.

35 Grundgesetz für die Bundesrepublik Deutschland z dnia 23maja 1949 r. (BGBl. s. 1). Art. 101 ust. 1 zd. 2 niemieckiej ustawy zasadniczej stanowi, że nikt nie może być pozbawiony prawa do sędziego ustawowego (Niemand darf seinem gesetzlichen Richter entzogen werden). 
utworzonym na mocy traktatów, który orzeka na podstawie przepisów prawa w sposób niezależny, i co do zasady ostateczny. Sędziowie Trybunału są niezawiśli i bezstronni. Postępowanie przed TSUE spełnia wymogi sprawiedliwego procesu, gwarantując m.in. prawo do wysłuchania, prawo do przedstawiania argumentów i obrony własnych interesów, stosownie do etapu postępowania. Jednocześnie art.267 TFUE przyznaje Trybunałowi Sprawiedliwości wyłączną właściwość do wiążącego rozstrzygania w przedmiocie wykładni traktatów oraz wykładni i ważności prawa pochodnego. Monopol w tym zakresie uzasadnia, zdaniem FSK, konieczność uznania Trybunału Sprawiedliwości za sędziego ustawowego w rozumieniu art. 101 ust. 1 zdanie 2 GG. W związku z tym, gwarancje dla podmiotów indywidualnych, wynikające $z$ art. 101 ust. 1 zdanie 2 GG, obejmują również roszczenie o zadanie przez sąd pytania prejudycjalnego, gdy zgodnie z art. 267 TFUE, sąd ten ma obowiązek zwrócić się do TSUE. W nowszym orzecznictwie, FSK zastrzega, że prawo do skargi przysługuje wyłącznie w przypadku arbitralnej decyzji sądu ostatniej instancji, rezygnującego ze zwrócenia się do ETS pomimo istnienia wyraźnych ku temu przesłanek ${ }^{36}$.

Podobne stanowisko można znaleźć w orzecznictwie austriackiego ${ }^{37}$ i hiszpańskiego sądu konstytucyjnego ${ }^{38}$.

Cechą wspólną tych sądów konstytucyjnych jest to, że mogą one uchylić orzeczenie sądowe w razie stwierdzenia jego niezgodności z konstytucją. Dzięki temu skarga konstytucyjna staje się dla jednostki dodatkowym środkiem prawnym, z którego może ona skorzystać, jeśli sąd zaniechał

36 Por. np. BverfG 2 BvL 12, 13/88, 2 BvR 1436/87, BVerfGE 82,159.

37 Zgodnie z orzecznictwem austriackiego Sądu Konstytucyjnego (Verfassungsgerichtshof, dalej jako VfGH), niezadanie pytania prejudycjalnego, gdy spełnione są kryteria sformułowane w Traktacie, narusza gwarantowane konstytucją prawo do postępowania przed sędzią ustawowym (Recht auf ein Verfahren vor dem gesetzlichen Richter). Zdaniem VfGH z podziału kompetencji pomiędzy sądy krajowe a TSUE wynika, że sądem właściwym dla rozstrzygnięcia wątpliwości z zakresu prawa unijnego jest Trybunał Sprawiedliwości. Niewystąpienie w takiej sytuacji z pytaniem prejudycjalnym powoduje, że sprawa zostaje w części rozstrzygnięta przez sąd niewłaściwy. To z kolei stanowi naruszenie prawa do postępowania przed sędzią ustawowym i sprawia, że orzeczenie staje się niekonstytucyjne. Sytuacja ta według austriackiego Sądu Konstytucyjnego ma miejsce nie tylko w przypadku rażącego, ale każdego naruszenia obowiązku przewidzianego w art. 234 ust. 3 TWE. Prezentuje on zatem bardziej liberalne stanowisko niż niemiecki FSK. Por. m.in. wyrok z dnia 26 czerwca 1997 r. VfGH B 3486/96, por. również wcześniejsze orzeczenie VfGH z 11 grudnia 1995 r., B2300/95.

38 W wyroku w sprawie nr 58/2004, hiszpański Tribunal Constitucional orzekł, iż arbitralna, oczywiście bezzasadna lub podjęta pod wpływem błędu, decyzja sądu o nieprzedłożeniu pytania prejudycjalnego, może skutkować naruszeniem prawa do sądu, a tym samym - hiszpańskiej Konstytucji. A. García, Spanish Constitutional Court; Tax on the use of gambling machines, „Common Market Law Review” 2005, nr 42, s. 535; K. Strąk, Pytanie wstępne w świetle orzecznictwa hiszpańskiego Trybunału Konstytucyjnego [w:] Pytanie prejudycjalne w orzecznictwie ETS. Funkcjonowanie procedury prejudycjalnej w Polsce, C. Mik (red.), Toruń 2006, s. 233. 
wystąpienia z pytaniem prejudycjalnym, a następnie wydał orzeczenie niezgodne z prawem unijnym. W Polsce Trybunał Konstytucyjny (dalej: TK) nie ma kompetencji do rewizji orzeczeń sądowych, więc złożenie tego rodzaju skargi konstytucyjnej nie byłoby możliwe.

Kwestia odmowy kierowania pytań prawnych, w tym pytań prejudycjalnych, pojawiła się także w orzecznictwie Europejskiego Trybunału Praw Człowieka (dalej: ETPCz). Z orzecznictwa tego można wysnuć wniosek, że Konwencja nie gwarantuje prawa dostępu do Trybunału Sprawiedliwości jako sądu właściwego. W sprawie Coëme i inni przeciwko Belgii ${ }^{39}, \mathrm{ETPCz}$ stwierdził, że prawo dostępu do sądu nie jest absolutne i może podlegać ograniczeniom, np.w postaci przesłanek - dopuszczalność apelacji. Tym bardziej więc nie można twierdzić, że art. 6 Konwencji gwarantuje jednostce absolutne prawo do postępowania $\mathrm{w}$ ramach procedury pytań prawnych przed innym sądem niż sąd rozpatrujący sprawę, nawet jeśli ów inny sąd jest wyłącznie właściwy do interpretacji konkretnych regulacji prawnych, a na sądzie rozpatrującym sprawę, ciąży na mocy odrębnych przepisów, obowiązek skierowania pytania prawnego. Sąd ten ma bowiem prawo samodzielnie ocenić, czy zadanie takiego pytania jest celowe dla rozstrzygnięcia toczącego się przed nim sporu, a zatem czy rzeczywiście obowiązek ten aktualizuje się $\mathrm{w}$ danym przypadku. Jednak w tym samym orzeczeniu ETPCz stwierdził, że nie można całkowicie wykluczyć sytuacji, w której odrzucenie wniosku strony o zadanie pytania prejudycjalnego mogłoby jednak stanowić naruszenie art. $6 \$ 1$ Konwencji, w szczególności jeśli decyzja sądu byłaby arbitralna. Podobne tezy zawarł ETPCz w orzeczeniach dotyczących pytań prejudycjalnych do Trybunału Sprawiedliwości ${ }^{40}$.

Oznacza to, że jednostka nie może żądać zadania pytania prejudycjalnego w każdym przypadku, a sąd rozpatrujący sprawę jest uprawniony do oceny, czy zachodzi sytuacja acte clair lub acte éclairé. Jednakże sąd powinien co najmniej wziąć pod uwagę stanowisko jednostki, a w razie odmowy zwrócenia się do TSUE, wyczerpująco uzasadnić swoją decyzję. W przeciwnym wypadku decyzja, zwłaszcza jeśli została podjęta przez sąd ostatniej instancji, może zostać oceniona jako arbitralna i tym samym naruszająca prawo do sądu przewidziane w art. 6 Konwencji. Wspomniane naruszenie nie będzie jednak polegało na niezapewnieniu jednostce dostępu do właściwego sądu rozumianego jako dostęp do Trybunału Sprawiedliwości, ponieważ takiego prawa Konwencja nie gwarantuje. Będzie ono

39 Wyrok w sprawie Coemei in. p. Belgii, skargi nr 32492/96, 32547/96, 32548/96, 33209/96 i 33210/9632492/96, 32547/96, 32548/96.

40 Wyrok z dnia 4 października 2001 r. w sprawie 60350/00, Canela Santiago p. Hiszpanii; decyzja z dnia 28 czerwca 1993 r. w sprawie 15669/89, F.S. $i$ N.S. p. Francji; decyzja z dnia 25 stycznia 2000 r. w sprawie 44861/98, Moosbrugger p. Austrii; decyzja z dnia 13 czerwca 2002 r. w sprawie 43454/98, Bakker p. Austrii; wyrok z 8 kwietnia 2014 r. w sprawie 17120/09, Dhahbip. Włochom; wyrok z dnia 28 sierpnia 2018 r. w sprawie 60934/13, Somorjai p. Wegrom. 
związane $\mathrm{z}$ naruszeniem prawa jednostki do rzetelnego procesu, w szczególności prawa do wysłuchania lub prawa do poznania uzasadnienia rozstrzygnięć sądu.

\section{Naruszenie prawa do sądu poprzez zadanie pytania prejudycjalnego}

Powyższe rozważania nie powinny jednak prowadzić do wniosku, że sądy powinny niejako na wszelki wypadek zadawać pytania prejudycjalne, żeby zapewnić stronom dostęp do TSUE.

Należy pamiętać, że prawo do sądu obejmuje nie tylko prawo dostępu do sądu, ale także prawo do rozstrzygnięcia sprawy w rozsądnym terminie i do tego, aby ochrona sądowa była skuteczna. Tymczasem $z$ uwagi na okres oczekiwania na rozstrzygnięcie TSUE, który wynosi średnio kilkanaście miesięcy ${ }^{41}$, strona może ponieść negatywne konsekwencje skierowania przez sąd pytania prejudycjalnego i związanego z tym znaczącego wydłużenia postępowania. Tytułem przykładu można wskazać, że przez cały okres zawieszenia postępowania sądowoadministracyjnego w oczekiwaniu na orzeczenie prejudycjalne, naliczają się odsetki za zwłokę w zapłacie zobowiązania podatkowego. Długotrwałość postępowania cywilnego może z kolei skutkować bezskutecznością egzekucji, ponieważ przez ten czas może pogorszyć się sytuacja finansowa dłużnika. W pewnych sytuacjach, zadanie pytania prejudycjalnego może więc doprowadzić do tego, że ochrona sądowa nie będzie skuteczna.

Skoro długotrwałość postępowania może mieć negatywny wpływ na sytuację stron, to należy rozważyć, czy może dojść do naruszenia prawa do sądu w związku ze skierowaniem przez sąd krajowy pytania prejudycjalnego do Trybunału Sprawiedliwości. W tym temacie wypowiadał się między innymi Europejski Trybunału Praw Człowieka, który uznał, że przedłużenie postępowania sądowego ze względu na skierowanie pytania prejudycjalnego, nie może być uznane za przewlekłość i naruszenie prawa do sądu w rozumieniu art. 6 Konwencji, a czasu oczekiwania na odpowiedź nie wlicza się do czasu postępowania, za który państwo ponosi odpowiedzialność ${ }^{42}$.

Problem potencjalnego naruszenia prawa do sądu poprzez zadanie pytania prejudycjalnego pojawia się także w sprawach rozstrzyganych przez sądy konstytucyjne państw członkowskich. W najnowszym orzecznictwie niemiecki FSK wskazuje, że naruszenie prawa do sędziego ustawowego może mieć miejsce nie tylko w przypadku arbitralnego odstąpienia od skierowania pytania prejudycjalnego, ale również w sytuacji, w której sąd

41 Trybunał Sprawiedliwości Unii Europejskiej, Sprawozdanie roczne 2020. Działalność sądownicza, https://curia.europa.eu/jcms/upload/docs/application/pdf/2021-06/ qd-ap-21-001-pl-n.pdf (dostęp: 1.10.2021), s. 230.

42 Wyrok z dnia 26 lutego 1998 r. w sprawie 20323/92, Pafitis p. Grecji, wyrok z dnia 30 września 2003 r. w sprawie 40892/98, Koua Poirezz p. Francji. 
zadaje pytanie prejudycjalne mimo braku właściwości Trybunału Sprawiedliwości w danej sprawie. Zdaniem FSK, jeśli sprawa mieści się poza zakresem stosowania prawa unijnego, to Trybunał Sprawiedliwości nie jest sędzią ustawowym w rozumieniu art. 101 niemieckiej ustawy zasadniczej. W takiej sytuacji może dojść do naruszenia prawa do sądu w wyniku rozpoznania sprawy przez sąd niewłaściwy ${ }^{43}$.

W tym kontekście należy zwrócić uwagę także na skierowany do polskiego TK wniosek Prokuratora Generalnego o stwierdzenie niekonstytucyjności art. 267 TFUE. We wniosku zakwestionowano wyżej wymieniony przepis, rozumiany w ten sposób, że uprawnia on sąd krajowy do zadania pytania prejudycjalnego w sytuacji, gdy rozstrzygnięcie Trybunału nie odnosi się do przedmiotu sprawy, a także w sprawach dotyczących ustroju władzy sądowniczej oraz postępowania przed sądami krajowymi ${ }^{44}$.

Wydaje się jednak, że opisane powyżej przypadki postępowań przed sądami konstytucyjnymi są nie tyle wyrazem troski o prawa jednostek, ale raczej toczącego się od wielu lat sporu o prymat pomiędzy sądami konstytucyjnymi a Trybunałem Sprawiedliwości ${ }^{45}$.

\section{Zakończenie}

Procedura prejudycjalna odegrała istotną rolę w rozwoju orzecznictwa w zakresie prawa do sądu i wypracowania określonych standardów w celu zapewnienia jednostkom ochrony tego prawa. Równocześnie orzecznictwo prejudycjalne dotyczące prawa do sądu wpłynęło na samą procedurę prejudycjalną, to jest na wykładnię pojęcia sądu w rozumieniu art. 267 TFUE.

Nie ulega też wątpliwości, że procedura ta stała się w ostatnich latach ważnym narzędziem obrony praworządności oraz niezależności polskich sądów.

43 Orzeczenie FSK z dnia 6 października 2017 r., 2 BvR 987/16.

44 W tej sprawie Rzecznik Praw Obywatelskich Adam Bodnar wniósł o umorzenie postępowania, wskazując, że TK badał już zgodność z Konstytucją RP wcześniejszego art. 234 Traktatu o Wspólnocie Europejskiej (wyrok z 11 maja 2005 r., sygn. K 18/04). Rzecznik podkreślił także, że jeśli TK wyda wyrok, którego skutkiem będzie powstrzymanie sądów krajowych od zwracania się do TSUE z pytaniami prejudycjalnymi, wówczas Polska naruszy zobowiązania wynikające z Traktatu akcesyjnego, TFUE i TUE. Ł. Starzewski, RPO do TK: prawo sądów do pytania TS UE jest związane z członkostwem Polski w Unii, https://bip.brpo.gov.pl/pl/content/rpo-do-tk-wyrok-powstrzymujacy -sady-od-zadawania-pytan-prejudycjalnych-naruszalby-zobowiazania-Polski (dostęp: 1.10.2021).

45 M. Mataczyński, Kto jest ostatecznym arbitrem konstytucyjności w Europie? Problem konfliktu kompetencji między Trybunałem Sprawiedliwości a krajowymi sądami konstytucyjnymi (na podstawie orzecznictwa Trybunału Sprawiedliwości Wspólnoty Europejskiej i niemieckiego Sądu Konstytucyjnego) [w:] Wymiar Sprawiedliwości w Unii Europejskiej, C. Mik (red.), Toruń 2001, s. 119. 
Niewątpliwie, temat procedury prejudycjalnej w kontekście prawa do sądu jest wielowątkowy i naznaczony trwającym od wielu lat sporem o to, kto jest ostatecznym arbitrem konstytucyjności w Europie. W dyskusji wokół kompetencji Trybunału Sprawiedliwości do oceny organizacji sądów krajowych czy uprawnień sądów krajowych do kierowania pytań prejudycjalnych, nie powinno umykać naszej uwadze, że celem nadrzędnym jest tutaj zapewnienie skutecznej ochrony prawnej konkretnym stronom postępowania przed sądem krajowym.

Należy pamiętać, że kwestie poruszane w pytaniach prejudycjalnych sądów krajowych i w orzecznictwie Trybunału Sprawiedliwości mają bardzo daleko idące konsekwencje natury praktycznej. Spór o kompetencje Trybunału Sprawiedliwości i sądów krajowych w ramach procedury prejudycjalnej nie ma więc charakteru wyłącznie doktrynalnego czy politycznego. Dotyczy on także, a może nawet przede wszystkim, prawa jednostki do rozstrzygnięcia jej sprawy z elementem unijnym przez niezawisły i bezstronny sąd, w tym - w razie wątpliwości z zakresu prawa unijnego - przez Trybunał Sprawiedliwości w postępowaniu prejudycjalnym. Istotną kwestią jest również to, żeby wydane orzeczenie mogło być uznane przez sądy innych państw członkowskich, a więc żeby uzyskana ochrona sądowa była w pełni skuteczna ${ }^{46}$. Z uwagi na oparcie systemu współpracy sądowej o zasadę wzajemnego zaufania, której podstawą jest zapewnienie przez państwa członkowskie określonych standardów praw człowieka, osiągnięcie tego celu nie jest możliwe bez odpowiedniej organizacji krajowego sądownictwa oraz respektowania prawa unijnego i orzecznictwa Trybunału Sprawiedliwości ${ }^{47}$.

\section{Bibliografia}

García A., Spanish Constitutional Court; Tax on the use of gambling machines, „Common Market Law Review” 2005, nr 42.

Grzelak A., Sakowicz A., Wymóg niezależności sądu krajowego jako element skutecznej ochrony sądowej (uwagi na tle wyroku TS z 19.11.2019 r. dla polskiego wymiaru sprawiedliwości), „Państwo i Prawo” 2020, nr 5.

$46 \mathrm{~W}$ postępowaniu cywilnym niezapewnienie prawa do postępowania przed niezależnym sądem może stanowić podstawę do odmowy uznania lub wykonania orzeczenia przez sąd innego państwa członkowskiego na podstawie rozporządzenia nr 1215/2012. W kontekście postępowania karnego można wskazać na możliwość odmowy wykonania europejskiego nakazu aresztowania, z uwagi na to, że w kraju, który zwraca się o przekazanie osoby ściganej, istnieje rzeczywiste ryzyko naruszenia prawa podstawowego do niezawisłego sądu (wyrok z dnia 25 lipca 2018 r. w sprawie C-216/18 PPU, LM, ECLI:EU:C:2018:586).

47 Por. w sprawach karnych wyrok z dnia 30 maja 2013 r. w sprawie C-168/13 PPU, Jeremy F. przeciwko Premier minister, ECLI:EU:C:2013:358; analogicznie w odniesieniu do współpracy sądowej w sprawach cywilnych wyrok z dnia 22 grudnia $2010 \mathrm{r}$. w sprawie C-491/10 PPU, Joseba Andoni Aguirre Zarraga przeciwko Simone Pelz, ECLI:EU:C:2010:828. 
Grzeszczak R., Krajewski M., „Sąd” w świetle przepisów art. 47 KPP oraz art. 267 TFUE, „Europejski Przegląd Sądowy” 2014, nr 6.

Kastelik-Smaza A., Pytania prejudycjalne do Europejskiego Trybunału Sprawiedliwości a ochrona praw jednostki, Warszawa 2010.

Mataczyński M., Kto jest ostatecznym arbitrem konstytucyjności w Europie? Problem konfliktu kompetencji między Trybunałem Sprawiedliwości a krajowymi sadami konstytucyjnymi (na podstawie orzecznictwa Trybunału Sprawiedliwości Wspólnoty Europejskiej i niemieckiego Sadu Konstytucyjnego) [w:] Wymiar Sprawiedliwości w Unii Europejskiej, C. Mik (red.), Torun 2001.

Łętowska E., Czego ucza odpowiedzi na pytania prejudycjalne dotyczacepolskiego wymiaru sprawiedliwości, „Palestra” 2020, nr 5, https://palestra.pl/pl/czasopismo/ wydanie/5-2020/artykul/czego-ucza-odpowiedzi-na-pytania-prejudycjalne -dotyczace-polskiego-wymiaru-sprawiedliwosci (dostęp: 1.10.2021).

Półtorak N, Kto jest związany zasada efektywnej ochrony prawnej - uwagi na tle orzecznictwa Trybunału Sprawiedliwości w sprawie „Unión de Pequeños Agricultores”, „Kwartalnik Prawa Publicznego” 2002, nr 3.

Półtorak N., Ochrona uprawnień wynikających z prawa Unii Europejskiej w postępowaniach krajowych, Warszawa 2010.

Scheuring K., Ochrona praw jednostki w postępowaniach przed sądami wspólnotowymi, Warszawa 2007.

Schiller K., Willkürliche Verletzung der Vorlagepflicht an den EuGH. Voraussetzungen für einen Verstoß gegen Art. 101 Abs. 1 Satz 2 GG, „Recht der internationalen Wirtschaft" 1988.

Sikora A., Glosa do wyroku TSUE z 27.02.2018 r., C-64/16, Associação Sindicaldos Juízes Portugueses (art. 19 TUE jako autonomiczny i samodzielny wzorzec kontroli legalności), „Państwo i Prawo” 2018, nr 11.

Skutki wyroków Trybunału Sprawiedliwości i Sąu Najwyższego dotyczacych Izby Dyscyplinarnej Sadu Najwyższego i Krajowej Rady Sadownictwa (debata w redakcji „Europejskiego Przegladu Sądowego” w dniu 17.12.2019 r.), „Europejski Przegląd Sądowy” 2020, nr 1.

Starzewski Ł., RPO do TK: prawo sądów do pytania TS UE jest związane z członkostwem Polski w Unii, https://bip.brpo.gov.pl/pl/content/rpo-do-tk-wyrok -powstrzymujacy-sady-od-zadawania-pytan-prejudycjalnych-naruszalby -zobowiazania-Polski.

Strąk K., Pytanie wstępne w świetle orzecznictwa hiszpańskiego Trybunału Konstytucyjnego [w:] Pytanie prejudycjalne w orzecznictwie ETS. Funkcjonowanie procedury prejudycjalnej w Polsce, red. C. Mik, Torun 2006.

Trybunał Sprawiedliwości Unii Europejskiej, Sprawozdanie roczne 2020. Działalność sq̨downicza, https://curia.europa.eu/jcms/upload/docs/application/ pdf/2021-06/qd-ap-21-001-pl-n.pdf (dostęp: 1.10.2021).

Velder Ch., Ein neuer gesetzlicher Richter?, Neue juristische Wochenschrift 1987.

Wróbel A., Uwagi w kwestii prawa obywateli Unii Europejskiej do sądu wspólnotowego (główne tezy) [w:] Prawo polskie a prawo Unii Europejskiej. Konferencja wydziałowa Wydziału Prawa i Administracji UW 28 luty 2003, E. Piontek (red.), Warszawa 2003.

Zawidzka A., Locusstandi osób fizycznych i prawnych na podstawie art. 230 TWE czas na zmiany [w:] Szkice z prawa Unii Europejskiej, t. I, Prawo instytucjonalne, E. Piontek, A. Zawidzka (red.), Kraków 2003. 


\section{Akty prawne i orzecznictwo}

Decyzja ramowa Rady z dnia 13 czerwca 2002 r. w sprawie europejskiego nakazu aresztowania i procedury wydawania osób między Państwami Członkowskimi, Dz. U. L 190 z 18.7.2002, s. 1.

Grundgesetz für die Bundesrepublik Deutschland z dnia 23 maja 1949 r. (BGBl. s. 1).

Karta Praw Podstawowych Unii Europejskiej, ELI: http://data.europa.eu/eli/treaty/ char_2012/oj.

Konwencja o Ochronie Praw Człowieka i Podstawowych Wolności z dnia 4 listopada 1950 r. (Dz. U. 1993 Nr 61, poz. 284).

Rozporządzenie Parlamentu Europejskiego i Rady (UE) nr 1215/2012 z dnia 12 grudnia 2012 r. w sprawie jurysdykcji i uznawania orzeczeń sądowych oraz ich wykonywania w sprawach cywilnych i handlowych, ELI: http://data.europa .eu/eli/reg/2012/1215/oj.

Traktat o Unii Europejskiej (wersja skonsolidowana) z dnia 13 grudnia 2007 r., ELI: http://data.europa.eu/eli/treaty/teu_2012/oj.

Wyrok TSUE z dnia 16 stycznia 1974 r. w sprawie 166/73, Rheinmühlen-Düsseldorf $v$ Einfuhr- und Vorratsstelle für Getreide und Futtermittel. ECLI:EU:C:1974:3.

Wyrok TSUE z dnia 6 października 1981 r. w sprawie 246/80, Broekmeulen v. Huisarts Registratie Commissie, ECLI:EU:C:1981:218.

Wyrok TSUE z dnia 10 kwietnia 1984 r. w sprawie 14/83, Sabine von Colson and Elisabeth Kamann p. Land Nordrhein-Westfalen, ECLI:EU:C:1984:153.

Wyrok TSUE z dnia 15 maja 1986 r. w sprawie 222/84, Marguerite Johnston przeciwko Chief Constable of the Royal Ulster Constabulary, ECLI:EU:C:1986:206.

Orzeczenie Bundesverfassungsgerichtz dnia 22 października 1986 r. w sprawie 2 BVR 197/83 (Solange II) BVerfGE 73, 339.

Orzeczenie Bundesverfassungsgericht 2 BvL 12, 13/88, 2 BvR 1436/87, BVerfGE $82,159$.

Wyrok z dnia 11 czerwca 1987 r. w sprawie 14/86,Pretore di Salo p.X, ECLI: ECLI:EU:C:1987:275.

Wyrok TSUE z dnia 15 października 1987 r. w sprawie 222/86, Union nationale des entraîneurs et cadres techniques professionnels du football (Unectef) p. Georges Heylens $i$ in., ECLI:EU:C:1987:442.

Decyzja ETPCz z dnia 28 czerwca 1993 w sprawie 15669/89, F.S. i N.S. p. Francji.

Wyrok z dnia 14 grudnia 1995 r. w sprawie C-312/93, Peterbroeck, Van Campenhout\&Cie SCS p. Belgii, ECLI:EU:C:1995:437.

Wyrok TSUE z dnia 5 marca 1996 r. w połączonych sprawach C-46/93 oraz C-48/93, Brasseriedu Pêcheur v. Niemcy $i$ The Queen p. Secretary of State for Transport ex parte Factortame Ltd $i$ in., ECLI:EU:C:1996:79.

Wyrok Verfassungsgerichtshof z dnia 26 czerwca 1997 r. VfGH B 3486/96.

Wyrok ETPCz w sprawie Coeme $i$ in. p. Belgii, skargi nr 32492/96, 32547/96, 32548/96, 33209/96 i 33210/96 32492/96, 32547/96, 32548/96.

Wyrok TSUE z dnia 17 września 1997 r. w sprawie C-54/96, Dorsch Consult Ingenieursgesellschaft p. Bundesbaugesellschaft Berlin, ECLI:EU:C:1997:413.

Wyrok ETPCz z dnia 26 lutego 1998 r. w sprawie 20323/92, Pafitis p. Grecji. 
Decyzja ETPCz z dnia 25 stycznia 2000 r. w sprawie 44861/98, Moosbrugger p. Austrii.

Wyrok TSUE z dnia 21 marca $2000 \mathrm{r}$. w połączonych sprawach od C-110/98 do C-147/98, Gabalfrisa $i$ in. p. Agencia Estatal de Administración Tributaria (AEAT), ECLI:EU:C:2000:145.

Wyrok ETPCz z dnia 4 października 2001 r. w sprawie 60350/00, Canela Santiago p. Hiszpanii.

Wyrok TSUE z dnia 27 listopada 2001 r. w sprawie C-424/99, Komisja p. Austrii, ECLI:EU:C:2001:642.

Decyzja ETPCz z dnia 13 czerwca 2002 r. w sprawie 43454/98, Bakker p. Austrii.

Wyrok TSUE z dnia 25 lipca 2002 r. w sprawie C-50/00 P, Unión de Pequeños Agricultores p. Radzie, ECLI:EU:C:2002:462; wyrok z dnia 19 czerwca 2003 r. w sprawie C-467/01, Ministero delle Finanze v EribrandSpA., ECLI:EU:C:2003:364.

Wyrok ETPCz z dnia 30 września 2003 r. w sprawie 40892/98, Koua Poirezz p. Francji.

Wyrok Tribunal Constitucional w sprawie nr 58/2004.

Wyrok TSUE z dnia 13 marca 2007 w sprawie C-432/05 Unibet (London) Ltd i Unibet (International) Ltd p. Justitiekanslern, ECLI:EU:C:2007:163.

Wyrok TSUE z dnia 17 lipca 2008 r. w sprawie C-66/08, Szymon Kozłowski, ECLI:EU:C:2008:437.

Wyrok TSUE z dnia 22 czerwca 2010 r. w połączonych sprawach C-188/10, Aziz Melki i C-189/10, Sélim Abdeli, ECLI:EU:C:2010:363.

Wyrok TSUE z dnia 5 października 2010 r. w sprawie C-173/09, Georgi Ivanov Elchinov v Natsionalnazdravnoosiguritelna kasa, EU:C:2010:581.

Wyrok z dnia 16 listopada 2010 r. w sprawie C-261/09, Gaetano Mantello, ECLI:EU:C:2010:683.

Wyrok TSUE z dnia 2 grudnia 2010 r. w sprawie C-225/09, Edyta Joanna Jakubowska p. Alessandro Maneggia, ECLI:EU:C:2010:729.

Wyrok TSUE z dnia 22 grudnia 2010 w sprawie C-491/10 PPU, Joseba Andoni Aguirre Zarraga przeciwko Simone Pelz, ECLI:EU:C:2010:828.

Postanowienie TSUE z dnia 19 stycznia 2012 r. w sprawie C-496/10, Postępowanie karne p. Aldo Patriciello, ECLI:EU:C:2012:24.

Wyrok TSUE z dnia 13 grudnia 2012 r. w sprawie C-465/11, Forposta SA i ABC Direct Contact sp. z o.o. p. Poczcie Polskiej SA, ECLI:EU:C:2012:801.

Postanowienie TSUE z dnia 21 marca 2013 r. w sprawie C-522/11, Procura della Repubblica p. Abdoul Khadre Mbaye, ECLI:EU:C:2013:190.

Wyrok TSUE z dnia 30 maja 2013 r. w sprawie C-168/13 PPU, Jeremy F. przeciwko Premier minister, ECLI:EU:C:2013:358.

Wyrok ETPCz z 8 kwietnia 2014 r. w sprawie 17120/09, Dhahbi p. Włochom.

Wyrok TSUE z dnia 5 kwietnia 2016 r. w sprawie C-689/13, Puligienica Facility EscoSpA (PFE) v. AirgestSpA, ECLI:EU:C:2016:199.

Wyrok TS z dnia 5 lipca 2016 r. w sprawie C-614/14, Postępowanie karne przeciwko Atanasowi Ognyanovowi, ECLI:EU:C:2016:514.

Opinia rzecznika generalnego Michala Bobeka z dnia 27 października $2016 \mathrm{r}$. w sprawie C-551/15, Pula Parking d.o.o. p. Svenowi Klausowi Tederahnowi, ECLI:EU:C:2016:825. 
Wyrok TSUE z dnia 21 grudnia 2016 r. w sprawie C-119/15, Biuro podróży „Partner” Sp. z o.o. sp.k. w Dąbrowie Górniczej przeciwko Prezesowi Urzędu Ochrony Konkurencji i Konsumentów, ECLI:EU:C:2016:987.

Orzeczenie Bundesverfassungsgericht z dnia 6 października 2017 r., 2 BvR 987/16.

Wyrok TSUE z dnia 27 lutego 2018 r. w sprawie C-64/16, Associação Sindicaldos Juízes Portugueses p. Tribunal de Contas, ECLI:EU:C:2018:117.

Wyrok ETPCz z 28 sierpnia 2018 r. w sprawie 60934/13, Somorjai p. Wegrom.

Wyrok TSUE z dnia 25 lipca 2018 r. w sprawie C-216/18 PPU, LM, ECLI:EU:C:2018:586.

Opinia rzecznika generalnego Gerarda Hogana z dnia 1 października 2019 r. w sprawie C-274/14, Banco de Santander SA, ECLI:EU:C:2019:802.

Wyrok TSUE z dnia 19 listopada 2019 r. w połączonych sprawach C-585/18, C-624/18 i C-625/18, A.K. p. Krajowej Radzie Sądownictwa i CP i DO p. Sądowi Najwyższemu, ECLI:EU:C:2019:982.

Wyrok TSUE z dnia 21 stycznia 2020 r. w sprawie C-274/14, Banco de Santander, ECLI:EU:C:2020:17.

Opinia rzecznik generalnej Juliane Kokott z dnia 23 stycznia 2020 r. w sprawie C-658/18, UX p. Governo della Repubblica italiana, ECLI:EU:C:2020:33.

Wyrok TSUE z dnia 26 marca 2020 r. w połączonych sprawach C-558/18 i C-563/18, Miasto Łowicz p. Skarbowi Państwa, ECLI:EU:C:2020:234.

Wyrok TSUE z dnia 2 marca 2021 r. w sprawie C-824/18, A.B. i in. p. Krajowa Rada Sądownictwa, ECLI:EU:C:2021:153.

Wyrok TSUE z dnia 9 lipca 2020 r. w sprawie C-272/19, VQ p. Land Hessen, ECLI:EU:C:2020:535.

Opinia rzecznika generalnego Bobeka $\mathrm{z}$ dnia 4 marca $2021 \mathrm{w}$ połączonych sprawach C-357/19 i C-379/19, Euro Box Promotion i in., ECLI:EU:C:2021:170.

\section{Procedura prejudycjalna w kontekście prawa do sądu}

\section{Streszczenie}

Procedura prejudycjalna odegrała istotną rolę w rozwoju orzecznictwa w zakresie prawa do sądu i wypracowania określonych standardów w celu zapewnienia jednostkom ochrony tego prawa. Równocześnie orzecznictwo prejudycjalne dotyczące prawa do sądu wpłynęło na samą procedurę prejudycjalną, tj. na wykładnię pojęcia sądu w rozumieniu art. 267 TFUE. W ostatnich latach procedura ta stała się także ważnym narzędziem obrony praworządności oraz niezależności polskich sądów.

Niewątpliwie, temat dotyczący procedury prejudycjalnej w kontekście prawa do sądu jest wielowątkowy i naznaczony trwającym od wielu lat sporem o to, kto jest ostatecznym arbitrem konstytucyjności w Europie. Stronom tego sporu nie powinno umykać, że chodzi tutaj nie tylko o kwestię prymatu czy jednolitej wykładni prawa unijnego, ale przede wszystkim o zapewnienie skutecznej ochrony prawnej konkretnym stronom postępowania przed sądem krajowym.

Słowa kluczowe: pytania prejudycjalne, art. 267 TFUE, prawo do sądu, niezależność sądów, niezawisłość sędziowska 
The Preliminary Ruling Procedure in the Context of the Right to a Fair Trial

Abstract

The preliminary ruling procedure has played an important role in the development of case law concerning the right to a fair trial as well as relevant standards to ensure that this right is actually granted to individuals. At the same time, the preliminary rulings on the right to a fair trial influenced the preliminary ruling procedure itself, i.e. the concept of a court within the meaning of Art. 267 TFEU. In recent years this procedure has also become an important tool in the defense of the rule of law and the independence of Polish courts.

Undoubtedly, the topic of the preliminary ruling procedure in the context of the right to a fair trial is complex and marked by a long-standing dispute over the issue who is the ultimate constitutional arbiter in Europe. It should not be overlooked in this dispute that it is not only about the primacy or uniform interpretation of EU law, but above all about providing effective legal protection to specific individuals being parties to the proceedings before national courts.

Keywords: preliminary references, Art. 267 TFEU, right to a fair trial, judicial independence 